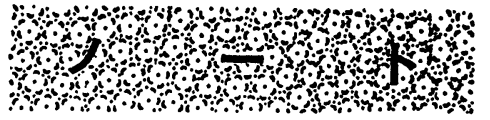

\title{
食用油脂中のクエン酸イソプロピル分析法
}

(昭和 62 年 1 月 6 日受理)

$$
\begin{array}{lll}
\text { 牛山博文* } & \text { 西島 基 弘* } & \text { 安田和 男* } \\
\text { 上 村 尚* } & \text { 田端 節子* } & \text { 二島太一郎* }
\end{array}
$$

\section{Determination of Isopropyl Citrate in Edible Oil}

\section{Hirofumi UshiYama, Motohiro Nishijima, Kazuo Yasuda, Hisashi Kamimura, Setsuko. TABATA and Taichiro Nishima}

(Tokyo Metropolitan Research Laboratory of Public Health: 24-1, Hyakunin-cho, 3-chome, Shinjuku-ku, Tokyo, Japan)

\begin{abstract}
An analytical method was developed for the determination of isopropyl citrate in edible oil.

The sample was dissolved in ethyl acetate and mono- and diisopropyl citrate were extracted with $5 \%$ sodium bicarbonate. The aqueous layer was acidified with phosphoric acid and isopropyl citrates were extracted with ethyl acetate. The ethyl acetate layer was dried with anhydrous sodium sulfate and evaporated to dryness. The residue was fluorescencelabeled with 4-bromomethyl-7-methoxycoumarin (Br-Mmc). Thin layer chromatography was used for the qualitative determination of fluorescence-labeled mono- and diisopropyl citrates.

Qualitative determination was carried out as follows. The sample was hydrolyzed with potassium hydroxide solution. The hydrolyzed solution was washed with hexane and applied to the Amberlite IRA-402 column. Citric acid was eluted with $1 N$ hydrochloric acid. The eluate was evaporated to dryness, and the residue was dissolved in water. High performance liquid chromatography was used for quantitative determination of citric acid.

The recoveries of isopropyl citrates added to edible oil were in the range from $84 \%$ to $93 \%$ and the detection limit of monoisopropyl citrate was $5 \mu \mathrm{g} / \mathrm{g}$.
\end{abstract}

(Received January 6, 1987)

Key words：食用油脂 edible oil; クエン酸イソプロピル isopropyl citrate; 酸化防止剤 antioxidant; 薄層クロマトグラフィー thin layer chromatography；高速液体クロマトグラフィー high performance liquid chromatography

クエン酸イソプロピルは昭和58年 8 月, 食品衛生法で 酸化防止剂として，食用油脂及びバターに使用すること が許可されだ.

クエン酸イソプロピルは，モノ，ジ及びトリイソプロ ピルの混合物で, 微量の金属イオンを封鎖して不活性化

\footnotetext{
* 東京都立衛生研究所：東京都新宿区百人町 3-24-1
}

し酸化を防止するが，ジ及びトリイソプロピルではその 効果はかなり低下するか，なくなる2). クェン酸イソプロピルの分析法は, ガスクロマトグラ

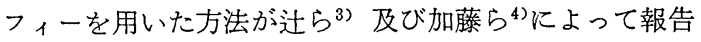
されている．著者らは酸化防止剂として効果の認められ る2)クェン酸モノ 及びジイソプロピルを 4-bromomethyl-7-methoxycoumarin (Br-Mmc) を用いて蛍光ラ 
ベル化を行い5), 薄層クロマトグラフィー (TLC) で定性 後, クエン酸モノ， ジ及びトリイソプロピルを加水分解 してクェン酸とし，クェン酸を高速液体クロマトグラフ ィー (HPLC) で定量後, 食品衛生法に基づく使用基準に 従いクエン酸モノイソプロピルに換算する方法を検討 し，良好な結果を得たので報告する。

\section{実験方法}

\section{1. 試 料}

市販の食用植物油 (綿実油, 大豆油), マーガリン及び バターを用いた。

\section{2. 試薬}

1）標準品：クエン酸モノ，ジ及びトリイソプロピル は辻らの報告 ${ }^{3} に$ 従って合成した.

2) $\mathrm{Br}-\mathrm{Mmc}$ 溶液: $\mathrm{Br}-\mathrm{Mmc}$ ((株) 同仁化学研究所 製) $50 \mathrm{mg}$ をアセトン $40 \mathrm{ml}$ に溶解したものを用いた.

3） 18-Crown-6: Aldrich 社製を用いた.

4) 水酸化カリウム溶液: 水酸化カリウム $9 \mathrm{~g}$ を水に 溶解し $10 \mathrm{ml}$ としたものを用いた.

5) 薄層用シリカゲルプレート: HPTLC Fertigplatten Kieselgel 60 (Merck 社製) を用いた.

6) 陰イオン交換樹脂カラム: 直径 $1.5 \mathrm{~cm}$ のガラス 管にアンバーライト IRA-402 (オルガノ(株)製)を 15 $\mathrm{cm}$ の高さに充てんしたものを用いた.

その他の試薬は市販の試薬特級品を用いた.

3. 装置

1) 紫外線照射器: Ultra-Violet 社製 TL-33 型

2) 自記蛍光分光光度計：（株）日立製作所製 MPF$2 \mathrm{~A}$ 型

3）高速液体クロマトグラフ：(株) 日本分光工業製 TRI-ROTAR-II 型

4) 検出器：（株）日本分光工業製 UVIDEC-100-III 型

5）高速液体クロマトグラフ用カラム：(株) 島津製作 所製 Shim-pack CLC-ODS $6 \mathrm{~mm}$ i.d. $\times 150 \mathrm{~mm}$

\section{4. 試験溶液の調製}

\section{1 定性用試験溶液}

試料 $10 \mathrm{~g}$ を酢酸エチル $50 \mathrm{ml}$ に溶解し, $5 \%$ 炭酸水 素ナトリウム溶液 $50 \mathrm{ml}$ を加えて振とうし, 水層を分取 した. 酢酸エチル層に $5 \%$ 炭酸水素ナトリウム溶液 50 $\mathrm{ml}$ を加えて同様に操作し, 水層は合やた. 水層にリン酸 を加えて酸性とした後, 酢酸エチル $100 \mathrm{ml}$ で 2 回抽出 した. 酢酸エチル層を合せ無水硫酸ナトリウムを加えて 脱水後, $40^{\circ}$ 以下で減圧乾固した.

残留物に $\mathrm{Br}-\mathrm{Mmc}$ アセトン溶液 $4 \mathrm{ml}, 18-$ Crown-6 $2 \mathrm{mg}$ 及び炭酸カリウム $4 \mathrm{mg}$ を加え, 混和した後, 80〜 $90^{\circ}$ で30分間還流して, クェン酸モノ及びジイソプロピ ルを蛍光ラベル化し, 定性用試験溶液とした。

\section{2 定量用試験溶液}

試料 $2 \mathrm{~g}$ を科取し, 酢酸エチル $50 \mathrm{ml}$ に溶解し, $5 \%$
Table 1. Conditions of High Performance Liquid Chromatography for Citric Acid

\begin{tabular}{lll}
\hline \hline Column & $:$ & Shim-pack CLC-ODS $6 \mathrm{~mm} \mathrm{i.d.}$ \\
& $\times 150 \mathrm{~mm}$ \\
Mobile phase $:$ & $0.1 \mathrm{MHH}_{2} \mathrm{PO}_{4} \mathrm{pH} 2.8$ \\
Flow rate $:$ & $0.8 \mathrm{ml} / \mathrm{min}$ \\
Detector $:$ & $210 \mathrm{~nm}$ \\
Sample size $:$ & $10 \mu 1$ \\
\hline
\end{tabular}

炭酸水素ナトリウム溶液 $30 \mathrm{ml}$ を加えて振とうし, 水層 を分取した. 酷酸エチル層は $5 \%$ 炭酸水素ナトリウム溶 液 $30 \mathrm{ml}$ を加え, 同様の操作をさらに 2 回繰り返した. 水層は合せ, 塩化ナトリウム $40 \mathrm{~g}$ を加え, リン酸を加え て酸性とした後, 酢酸エチル $150 \mathrm{ml}$ で 3 回抽出した. すべての酢酸エチル層は合せ， $40^{\circ}$ 以下で減圧乾固し た.

残留物にエタノール $30 \mathrm{ml}$ 及び水酸化カリウム溶液 $2 \mathrm{ml}$ を加え, 沸騰水浴中で 30 分間還流し, 加水分解し た. 冷後, 加水分解物を, 水 $10 \mathrm{ml}$ を用いて分液漏斗に 洗い込み, 塩酸で中和した後，へキサン $50 \mathrm{ml}$ を加えて 振とらし, 水層を分取した. 水層は, あらかじめ作製した 陰イオン交換樹脂 カラムに負荷した. 次いで水 $200 \mathrm{ml}$ で洗浄した後, $1 N$ 塩酸 $120 \mathrm{ml}$ でクェン酸を溶出した. 溶出液は減圧乾固し, 残留物に水 $2 \mathrm{ml}$ を加え溶解した ものを定量用試験溶液とした。

\section{5. 薄層クロマトグラフィーによる定性}

定性用試験溶液 $20 \mu \mathrm{l}$, 及びクェン酸モノ 及び ジイソ プロピルを同様に虽光ラベル化した標準品を，シリカゲ ルプレートに塗布し, 展開溶媒クロロホルムーアセトン (95:5) 混液を用い約 $6 \mathrm{~cm}$ 展開した. 風乾後, 柴外線照 射下で，スポットの $\mathrm{R} f$ 及び蛍光の色調を比較し, 定性 を行った。

\section{HPLC による定置}

定量用試験溶液を HPLC を用い, Table 1 に示した 条件でクェン酸を定量し，クェン酸モノイソプロピルに 換算した。

\section{結果及び考察}

\section{Br-Mmc による蛍光ラベル化}

クェン酸モノ及びジイソプロピルの蛍光ラベル化は, カルボン酸のラベル化剤である $\mathrm{Br}-\mathrm{Mmc}$ を用い, Grushka らの方法 ${ }^{5}$ に準じて行った. TLC で分離後, 励起 スペクトル及び蛍光スペクトルを測定した. クェン酸モ ノ及びジイソプロピルのラベル化物はいずれも極大励起 波長 $346 \mathrm{~nm}$, 極大蛍光波長 $446 \mathrm{~nm}$ のほぼ同様のパタ ーンを示した. Fig. 1 にクェン酸モノイソプロピルのラ ベル化物のスペクトルを示した. 励起波長 $346 \mathrm{~nm}$ のと き蛍光強度が極大となったが，一般に用いられる紫外線 照射器の波長である $365 \mathrm{~nm}$ では, 蛍光強度は $346 \mathrm{~nm}$ のときの約 $65 \%$ であるが，植物油及びバターに応用し 


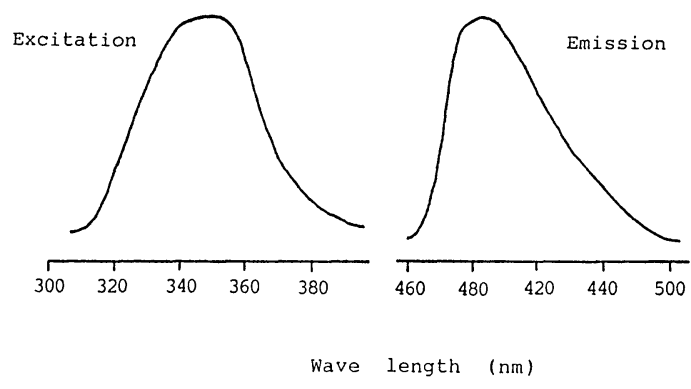

Fig. 1. Fluorescence excitation and emission spectra of monoisopropyl citrate derivative

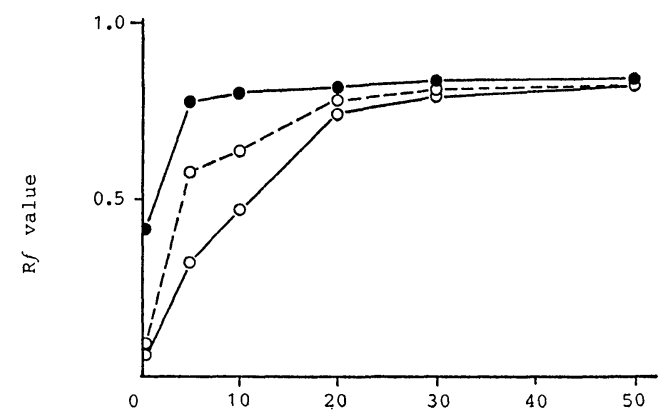

Concentration of acetone

(\%)

Fig. 2. Relation between $\mathrm{R} f$ values of isopropyl citrate derivatives and concentration of acetone in solvent system

solvent system: chloroform-acetone

-—: Br-Mmc, ○-○: monoisopropyl, ○-.-: diisopropyl

たときの確認限度は，スポットあたり，モノ及びジイソ プロピル共に $0.2 \mu \mathrm{g}$ で, 定性試験としては実用上問題 なかった.

\section{TLC による定性}

\section{1. 展開溶媒}

Dünges ${ }^{\text {() }}$ はBr-Mmc でラベル化した脂肪酸の TLC による分離に，ベンゼンー酢酸 エチル系の展開溶媒を用 いているが，本法に応用したところ，特にラベル化物及 び $\mathrm{Br}-\mathrm{Mmc}$ の相互分離の点で満尼いく結果は得られな かった．そこで種々の展開溶媒を検討したところ，ク口 ロホルムーアセトン混液を用いたとき，スポットのまと まり及び相互分離の点で，良好な結果が得られたため， クロロホルムーアセトン混液について, 最適の条件を検 討した. Fig. 2 に示したようにアセトンの混合割合が増 加するに従い，クェン酸モノ及びジイソプロピルのラベ ル化物及び $\mathrm{Br}-\mathrm{Mmc}$ の $\mathrm{R} f$ が大きくなる傾向を示した. クロロホルムとアセトンの比が 95:5 のとき，相互の分 離が良好で，かつ食用油脂に応用した際の妨害物との分

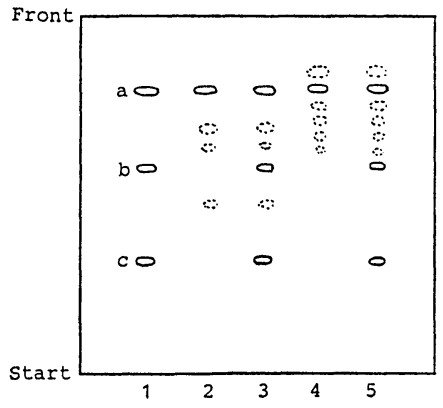

Fig. 3. Thin layer chromatogram of $\mathrm{Br}-\mathrm{Mmc}$ reaction mixtures of isopropyl citrates and sample extracts

a: Br-Mmc, b: diisopropyl, c: monoisopropyl

1: mono and diisopropyl citrates, 2: cottonseed oil extract, 3: cottonseed oil extract + mono and diisopropyl citrates, 4: butter extract, 5: butter extract+mono and diisopropyl citrates

離が良かったことから, 展開溶媒はクロロホルムーアセ トン (95:5) を用いることにした。

綿実油及びバターに応用したとさの薄層クロマトグラ ムを Fig. 3 に示した. いずれの場合も，スポットの $\mathrm{R} f$ 及び蛍光の色調から定性が可能であった。

\section{3. 妨害物の検討}

本法を用いた際，定性用試験溶液と同じ画分に分画さ れる食品添加物, 及び食用油脂及びバターに添加される 可能性がある食品添加物あるいは成分として含まれる物 質としてクェン酸, 安息香酸, ソルビン酸, プロピオン 酸, デヒドロ酢酸, BHA 及び BHT について検討した. クエン酸は定性用試験溶液の画分に分画されないため, 妨害とはならなかった. 安息香酸, ソルビン酸及びプロ ピオン酸は Rfがそれぞれ 0.9 以上で, クェン酸イソプ ロピルのラベル化物と明らかに異なるため区別ができ た. また BHA，BHT 及びデヒドロ酢酸は定性用試験溶 液の画分に分画されないか，あるいはラベル化されない ため，いずれも妨害とはならなかった。

\section{4. 陰イオン交換樹脂カラムクロマトグラフィー}

加水分解して得た溶液は，妨害物質により粘度が高く 濃縮が困難で，そのままでは HPLC でクェン酸を分析 することができなかった. そこで，共存する妨害物質の 除去を検討した. クエン酸はカルボキシル基を有するこ とから，陰イオン交換樹脂カラムクロマトグラフィーを 検討した.

\section{1. 陰イオン交換樹脂量}

樹脂の量とクエン酸の回収率の関係を Fig. 4 に示し た. カラムの高さが $12 \mathrm{~cm}$ 以上で，クエン酸はほぼ $100 \%$ 回収されることから, カラムの高さは $15 \mathrm{~cm}$ とす 
Table 2. Recovery of Mono-, Di- and Triisopropyl Citrate Added to Cottonseed Oil and Butter

\begin{tabular}{lcccc}
\hline \multirow{2}{*}{ Sample } & Added $(\mu \mathrm{g})$ & \multicolumn{3}{c}{ Recovery (\%) } \\
\cline { 3 - 5 } & & Monoisopropyl & Diisopropyl & Triisopropyl \\
\hline Cottonseed oil & 200 & $90 \pm 2.4$ & $91 \pm 2.5$ & $93 \pm 1.8$ \\
Butter & 50 & $87 \pm 3.3$ & $88 \pm 2.9$ & $89 \pm 2.1$ \\
& 200 & $87 \pm 3.6$ & $91 \pm 3.3$ & $90 \pm 3.1$ \\
& 50 & $84 \pm 4.6$ & $87 \pm 3.8$ & $86 \pm 3.9$ \\
\hline
\end{tabular}

Sample: $2 \mathrm{~g}$, average for 4 trials

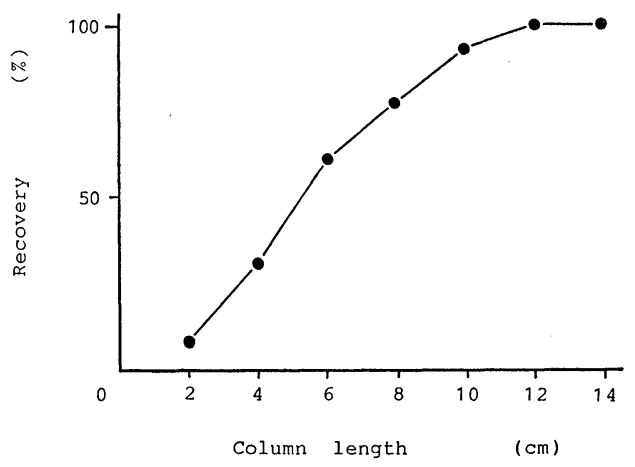

Fig. 4. Recovery of citric acid by different resin volume in the column

resin: Amberlite IRA-402, column i.d.: $1.5 \mathrm{~cm}$

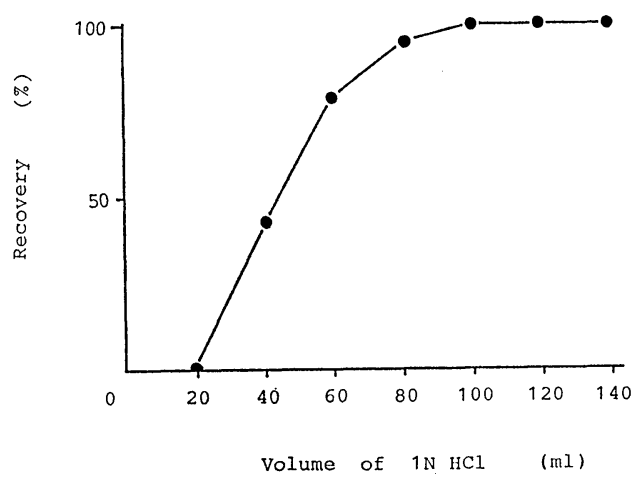

Fig. 5. Recovery of citric acid from an Amberlite IRA-402 column with $1 N$ hydrochloric acid

\section{ることにした.}

\section{2. 溶出溶媒量}

溶出溶媒として $1 N$ 塩酸を用いた場合のクエン酸の 溶出パターンを Fig. 5 に示した. クェン酸は $100 \mathrm{ml}$ で ほぼ $100 \%$ 溶出することから，溶出に用いる $1 N$ 塩酸 の量は余裕をみて $120 \mathrm{ml}$ とした.

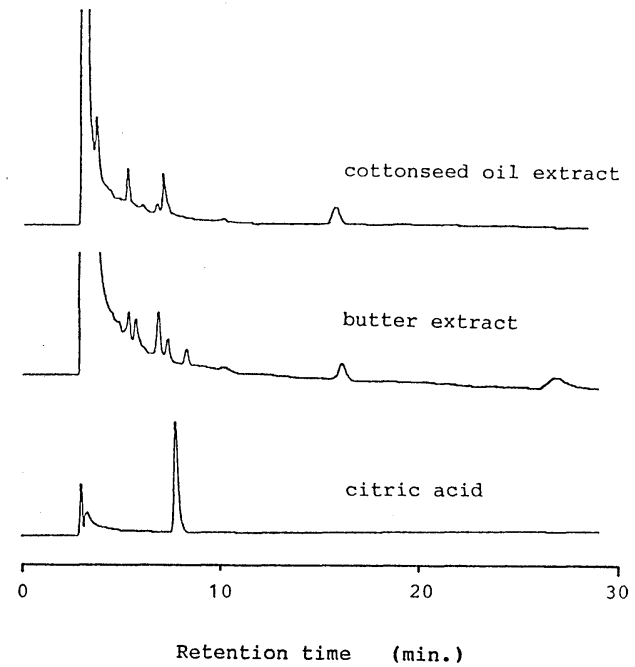

Fig. 6. High performance liquid chromatograms of citric acid and sample extracts

\section{HPLC の条件}

\section{1. カラムの選択}

従来からHPLC による有機酸などのイオン性物質の 分離には, イオン交換クロマトグラフィーが主として用 いられているが7)，イオン交換クロマトグラフィーは, 再 現性や，カラムの寿命の点などいくつかの難点を持つ. そこで逆相クロマトグラフィーとして用いられるカラム である Shim-pack CLC ODS を用い，イオン化抑制法 によるクエン酸の分析を検討した.

\section{2. 移動相の検討}

$0.1 M$ リン酸二水素カリウム溶液を用い,リン酸で $\mathrm{pH}$ を 4 から 2.6 まで変化させ最適の条件を検討した。 $\mathrm{pH} 4$ ではクェン酸の保持が不十分で，分析できなかっ た. $\mathrm{pH} 3.2$ から 2.6 のとさクエン酸は良好に保持され， テーリングもなく良好なピークが得られた。 また食品に 応用した場合も良好な結果が得られたことから，移動相 は $0.1 M$ リン酸二水素カリウム溶液をリン酸で $\mathrm{pH}$ を 2.8 に調整し，用いることにした。 


\section{6. 食用植物油及びパターへの応用}

本法を綿実油及びバターへ応用したときのクロマトグ ラムをFig. 6 に示した。特に妨害は認められず，良好な 結果が得られた。また，試料にクェン酸を $200 \mu \mathrm{g}$ 添加 し，本法に従って試験した場合でも，特に影響は見られ なかった.

\section{7. 添加回収試験}

あらかじめ、クエン酸イソプロピルが存在しないこと を確認した綿実油及びバター $2 \mathrm{~g}$ に，クエン酸モノ，ジ 及びトリイソプロピルをそれぞれクェン酸として50及び $200 \mu \mathrm{g}$ 添加し, 本法に従って回収試験を行った結果を Table 2 に示した. 回収率は 84〜93\%, 標準偏差 1.8〜 $4.6 \%$ と満足できる結果が得られた.

定量限界は試料中モノイソプロピルとして $5 \mu \mathrm{g} / \mathrm{g}$ で あった。

\section{8. 市販品の使用実態調查}

本法を用い, 市販の綿実油, 大豆油, マーガリン及びバ ターなぞ, 計13検体について使用実態調查を行ったが, いずれからもクエン酸イソプロピルは検出されなかっ た.

\section{ま とめ}

食用油脂中のクエン酸イソプロピルの分析法を検討し た。

試料から酢酸エチルで，クエン酸イソプロピルを抽出 後, $\mathrm{Br}-\mathrm{Mmc}$ で営光ラベル化を行い, TLC で定性を行
った.クエン酸イソプロピルを検出した場合，あるいは 判定が困難なるのについては, 試料に水酸化カリウム溶 液を加え，還流を行い加水分解して得たクエン酸を HPLC で定量した. 回収率は 84 93\%，定量限界は試料 中モノイソプロピルとして $5 \mu \mathrm{g} / \mathrm{g}$ であった.

市眅の植物油，マーガリン及びバターについて調査し たところ，いずれからもクェン酸イソプロピルは検出さ れなかった。

文献

1）仲本典正，平山佳伸，松田 勉，山本芳子：食品 衛生研究 33, 831 889 (1983).

2) 太田静行：New Food Industry 25, 44 49 (1983).

3）辻 澄子, 外海泰秀, 伊藤誉志男, 原田基夫：食 衛誌. 26, 357 364 (1985).

4) 加藤ク二, 中岡正吉, 伊藤和敏：同上 $27,668 \sim$ 671 (1986).

5) Eli G., Stanley L., John C.: Anal. Chem. 50, 1398 1399 (1978).

6) Wolfgang D.: ibid. 49, 442 445 (1977).

7）液体クロマトグラフ研究会データ 集積委員会編: “高速液体クロマトグラフィーデータ集” 92, 96, 109, 1525, 1528, 1532, 2794, 3384, (1977)（株） アイピーシー。 